\title{
Present scenario of gift tax in Bangladesh: contribution and prospect in the economy.
}

\author{
Md. Rayhanul Islam, Nurul M Zayed* \\ Department of Real Estate, Daffodil International University, Dhaka, Bangladesh
}

\begin{abstract}
Gift tax is a direct tax in nature which is levied on the taxable gifts under Gift Tax Act-1990 that was adopted from Pakistani Gift Tax Act 1963 with some modifications in Bangladesh. In some countries gift tax and inheritance tax is one and the rate of inheritance tax depends on the closeness of the relationship. Gift consists of the extinction of one's own property and the generation of another property, that can also be termed as present and Gift tax is paid on the gifted money or money's worth. Gift tax is digressive in structure of tax rate. Generally up to Tk 20,000 of gifts is exempted from tax. The valuation of gifts should be made according to the rules prescribed in Gift Tax Act 1990. However gifts made to spouse and blood related persons like parents, own brothers and sisters and the gift of property situated outside Bangladesh are normally exempted from taxation. Moreover gifts made to charitable institutions are also exempted from taxation even government enjoys the power to exempt any gifts from taxation. Although there are provision and laws of gift tax, still the collection of tax revenue from this source is not mentionable but the scenario can be changed by taking necessary steps by the respective authorities.
\end{abstract}

Keywords: Gift tax, Tax revenue, Inheritance tax, Government revenue, Control mechanism.

Accepted on July 25, 2018

\section{Introduction}

The term "tax" which has close relation with the Latin word "taxare" has been derived from a French word "taxe" which means to charge [1]. And the tax can only be charged by the state. Tax is compulsory or mandatory payment to the government by selected group of people without expecting any direct benefit in return. In most of the times taxation refers to the act of taxing authority (National Board of Revenue in Bangladesh) exercising the power of levying tax [2]. According to Article 152 (1) of the Constitution of Bangladesh "taxation includes the imposition of any tax, rate, duty or impost, whether general, local or special and tax shall be constructed accordingly" [3]. At present tax revenue has been considered as a major source of government revenue in every country. According to section 2 (62) of the Income Tax Ordinance 1984, "tax means the income tax payable under the ordinance and includes any additional tax, excess profit tax, penalty, interest, fees or other charges leviable or payable under this ordinance". Unfortunately taxes are considered as a burden by everyone. But actually taxation is not like that at all. The tax revenues collected by the government are used for the public sector development that opens the door of opportunities to the people in various ways. Tax is the prime source of government revenue no doubt, at the same time it intends to minimize the inequalities in income and wealth which is done by imposing more tax on rich people and conferring benefits to the poorer section of the society. In addition to that, tax controls the consumption of luxurious and unhealthy goods that indirectly plays the roles of a control mechanism which prescribes higher tax for unhealthy and luxurious goods. Besides that tax works as a safeguard to the integrities of both the estate and income taxes [4]. Tax further safeguards the local developing and poor industries from the uneven completion by providing tax incentives to them. All the above things are done to ensure overall economic development of the country. Gift tax is a minor source of tax revenue in Bangladesh about which most of the people do not have clear-cut idea; even some people do not have any idea at all. Collection of gift tax is not mentionable yet but its contribution to the economy can be increased by taking some steps.

Taxation system of a country is one of the vital issues for the good governance. In Bangladesh Tax-GP ratio is only 10.5\% which is very low compared to South East Asian average of $16 \%$, OECD average of $34 \%$ and world average of $27 \%$. The reasons for the low Tax-GDP ratio might include that, in Bangladesh the tax rate for the wealthy people is low, not only that, even actual tax collection is low although the tax rate is not that much low. Besides, wealth tax, gift tax, property transfer tax and inheritance tax are absent here. The reason may also include the very small percentage of personal tax collection as a percentage of GDP. In Bangladesh percentage of personal tax collection with GDP is $0.88 \%$ compared to India's 2.29 percent, Thailand's 2.4 percent and Indonesia's 2.9 percent [5]. Among many types of taxes gift tax is a direct tax. Being an unpopular type of tax, tax payers don't have 
Citation: Islam MDR, Zayed NM. Present scenario of gift tax in Bangladesh: contribution and prospect in the economy. J Fin Mark. 2018;2(3):10-13.

sufficient knowledge about it. By applying the gift tax rules, collection of total tax revenues can be improved.

\section{Objectives of the Study}

The objectives of the study include presenting the current scenario of gift tax in Bangladesh. The objectives also include providing an overall idea about the gift tax to the learners. Further the study will try to present weather the Gift tax can make any contribution for the economy of the country. Besides, the objectives include finding out some scopes for further research in this field. Finally the audiences will get some interesting information about gift tax in Bangladesh from this paper.

\section{Methodology}

This is mainly a desk research where relevant literatures have been reviewed to understand the concept of gift tax and to present the scenario of it in Bangladesh. Data and information were collected from various published sources including books, related journals and various related websites. After collection, the data were analyzed from the perspective of Bangladesh. Some tables were used to present relevant information.

\section{Background of the Study}

Currently almost all the countries of the world follow multiple tax system with several types of direct and indirect taxes. In the developing countries, over dependency on indirect taxes is one of the main obstacles towards attaining the economic development [6]. Bangladesh has the multiple tax system and we also have various types of taxes like income tax, VAT, excise duty, gift tax etc. Presently in most of the developed countries like USA, UK and Canada taxes contribute a lot for the economy where gift tax also has some contribution. But in Bangladesh gift tax collection is absent and has zero contribution to the government revenue. There are rules and regulation about the gift tax but receipt of gift tax is almost nil. If the reasons behind this scenario can be found and necessary steps are taken, a substantial amount of revenue might be collected from gift taxation in Bangladesh and consequently that will result an increase in tax revenue and subsequently will reduce the country's dependence on foreign aid. National Board or Revenue intends to develop sound tax laws and policies according to the international best practices [7].

\section{Limitations of the Study}

The concept of Gift Tax is not well known to the people like any other tax. It is not a popular one and so enough information of gift tax is not available. In Bangladesh no article was found on gift tax. Even the Tax Text Books and the website of the National Board of Revenue (NBR), the tax collecting authority in Bangladesh do not contain sufficient information about gift tax.

\section{History of Gift Tax}

Taxes on the transfer of wealth were levied in Egypt as far back as in the $7^{\text {th }}$ century BC (Reforming the Gift Tax and
Making It Enforceable, Page 11). In the United States Gift tax was first enacted in the year of 1924, repealed in 1926 and overhauled and reintroduced in 1932 [8]. At present in the United States, the gift tax is governed by Chapter 12, Subtitle $\mathrm{B}$ of the Internal Revenue Code. 5 percent inheritance tax on all the inheritances was initiated by Roman Empire Caesar Augustus to initiate a retirement funds for the military. But gifts to children and spouse were exempted [9]. The Gift Tax Act, 1958 was an Indian legislation passed in 1958 to impose tax on giving or receiving gifts under certain circumstances. It was applicable to all the States and Union Territories of India with the exception of the State of Jammu and Kashmir.

In the undivided Pakistan Gift Tax Act 1963 was enacted and up to the liberation of Bangladesh that Act was in force in Pakistan. After the independence, Bangladesh adopted the Pakistani Gift Tax Act 1963 with some modifications and changes. Later it was repealed in the year of 1985 through Section 4 of Finance Ordinance and came into force on $1^{\text {st }}$ July 1990 and the name of the Act was changed to "Gift Tax Act,1990" (Act No. 44). At present Gift Tax Act 1990 has 21 Sections, one subsection and one schedule that contain the rates of gift tax with reference to section-3. Besides the Gift Tax Act 1990, in Bangladesh Gift Tax Rules 1990 are also applicable and so far 6 rules and 5 form formats have been issued by National Board of Revenue (NBR). Gift tax has been collected in Bangladesh since 1963 by the income tax authority except from 1985-1986 to 1989-1990. But still collection of gift tax is not mentionable in Bangladesh.

\section{Gift and Gift Tax}

Generally gift means something giving freely, in otherword it can be termed as a present. According to the United States Internal Revenue Service, gift is "Any transfer to an individual, either directly or indirectly, where full consideration (Measured in money or money's worth) is not received in return". On the other-hand gift means any transfer of ownership of moveable or immoveable property by one person to another willingly and without any profit. For something to be considered a gift, the receiving party cannot pay the giver full value for the gift, but may pay an amount less than its full value.

Hindu law defines gift as "the creation of another person's proprietary right after the extinction of one's own proprietary right into subject matter of gift" [10]. Gift consists of the extinction of one's own property and the generation of another property; and if that another party accepts, then and not otherwise the generation of another's property becomes complete.

Most people do not think that tax maybe applied on gift amount. Even they cannot imagine about the imposition of tax on gift as well as logic for imposing gift tax. If tax is not imposed on gift, people will transfer the property in the form of gifting instead of selling or buying. Because registration cost of property like- land, apartment, commercial space is high. Since Gift tax is a federal tax applied to an individual giving anything of value to another person. This tax is a direct tax in nature, so it cannot be shifted to others. Gift 
tax is imposed on the transfer of property by means of gift. Basically gift tax is a tax on the transfer of property by one person to another while receiving nothing or less than full value in return. Tax is applicable, no matter whether the donor intends the transfer to be a gift or not. Besides the bequests at the time of death, inter-vivo gifts (during life) are also subject to estate tax [11]. In Bangladesh gift tax is leviable on the taxable gifts made at the rates specified in the schedule to the Gift Tax Act 1990 (Act no. 44 of 1990). Under the gift tax Act 1990, now it is payable by the donor and applicable for the gifts of domestic property donated to the entities other than spouse, blood related family members and other dependent relatives, government recognized educational, charitable, religious, disaster management or medical established, local authorities and some other prescribed persons. Gift tax is digressive in nature where tax is progressive up to a certain limit and after that, tax rate remains constant. It is very important to state that in case of gift tax transfer of property must be made voluntarily without fear and favor. However in developed countries, unlike other taxes, gift tax does not serve an independent purpose, rather it is designed to protect the integrity of the estate tax and the income tax. In economics, a gift tax is the tax on money or property that one living person gives to another.

Inheritance tax is another concept related to the gift tax. In some countries inheritance tax and gift tax are one [12]. Inheritance tax is a tax which is imposed on the assets inherited from a deceased person. It is termed as "death duty" in some countries [13]. Inheritance tax (IHT) is a tax on money or possessions one leave behind when she/ he dies. Some countries around the world levy this tax. The inheritance tax rate depends on the value of the property received by the heir and the relationship between the heir and the decedent. The closely related peoples like parents, Children, grandparents have to pay lower inheritance tax compared to the people with distant relationship like aunts, uncles, nieces and nephews etc. [4]. This tax is also known as a "death duty" in some countries. Presently highest rate of inheritance tax is found in Japan which is $55 \%$ while the average rate for the OECD countries is $15 \%$ [14].

\section{Valuation of gift}

Gift taxation is a controversial subject and the valuation of gift is a complex issue in gift tax because the actual value of gifted property may not be available always [15]. Although the assets like cash, stocks and bonds, mutual funds, even houses and cars are easily valued because of availability of market value, things like ownership interests in privately owned businesses, investments in oil or gas wells and artwork are hard to value. Valuation of gifts is a painstaking task to the Certified Public Accountants (CPAs) [16]. However adequate disclosures regarding the valuation of the gifted assets may reduce the complexity and increase the reliability for the assessment of gift tax. Gift tax is applicable on the market value of the gifted property. But if the market value is not available, the rules prescribed in Section-5 and Rule- 6 of Gift Tax Act and Rules-1990 is applicable. From the legal perspective, valuation of gift is made and shown in Table 1.

\section{Gifts exempted from taxation}

According to section 4 of the Gift Tax Act 1990 a number of gifts are exempted from taxation:

- If the gifted property is situated abroad.

- Gift made to local or central government, educational institutions, recognized polytechnic institutes etc.

- Gifts to any hospital recognized or run or aided by the government or local authority.

- Gifts to any government approved natural calamity management funds.

- Gifts to any institution for charitable or religious purpose established in Bangladesh and approved by the government or established or registered under any law in force in Bangladesh. In this case the gifted amount cannot exceed $20 \%$ of the total income of the assesse or Tk 100,000 whichever is lower in the respective assessment year.

- Gifts made to any dependent relatives on the occasion of his/her marriage to the extent of Tk 20,000

- Gifts by means of insurance policies or annuities to any person except one's spouse for his/her support and maintenance up to $\mathrm{Tk} 20,000$.

- Gifts under will and gifts in contemplation of death.

- Gifts to blood connected peoples like children, parents etc. Moreover basic exemption in gift tax is Tk 20,000 and the government reserves the right to exempt any classes of gifts or persons from the by way of gazette Notification.

\section{Gift tax rate}

Gift tax rate is digressive in nature with four tiers. In Bangladesh the gift tax rates with the value of taxable gifts are as under according to the Schedule of Gift Tax Act 1990 and shown in Table 2 .

Table 1: Property Valuation Rules for Gift Tax Purpose.

\begin{tabular}{|c|l|}
\hline Property Type & \multicolumn{1}{c|}{\begin{tabular}{c} 
Rules Regarding Valuation \\
\hline Cash
\end{tabular}} \\
\hline $\begin{array}{l}\text { In this case two situations may arise. When market value is known: The price that the property would fetch if sold in the open market } \\
\text { on the date of gifting. } \\
\text { When the market value of the property is unknown: } \\
\text { Property other than cash } \\
\text { The value shall be determined in the manner prescribed in the Gift Tax Rules [Section 5(2)] as stated below: } \\
\text { 2. In case of gifted insurance policy, the price will be the amount that would be received by encasing the policy. } \\
\text { assets of the respective company or firm in the year in which the shares were gifted }\end{array}$ \\
\hline Other Property & \multicolumn{1}{|c|}{ As per the decision of National Board of Revenue (NBR) } \\
\hline
\end{tabular}


Citation: Islam MDR, Zayed NM. Present scenario of gift tax in Bangladesh: contribution and prospect in the economy. J Fin Mark. 2018;2(3):10-13.

Table 2: Current Gift Tax Rates in Bangladesh.

\begin{tabular}{|c|c|}
\hline Value of taxable gifts & Tax rate \\
\hline On first Tk. 500,000 & $5 \%$ \\
\hline On next $1,000,000$ & $10 \%$ \\
\hline On next $2,000,000$ & $15 \%$ \\
\hline On rest amount & $20 \%$ \\
\hline
\end{tabular}

\section{Tax Governance Framework in Bangladesh}

Income tax authorities hold the all responsibilities to execute the related laws, rules and regulations relating to tax. In Bangladesh, relevant necessary provisions are constituted in the Income tax ordinance-1984 to ensure efficient administration and to discharge executive and other sections. In Bangladesh NBR is the apex body to appoint income tax authorities according to the Income Tax Ordinance-1984 subject to the rules and orders of the government. Income tax authorities have been classified into administrative and judicial groups.

\section{Recommendations and Conclusion}

The contribution of tax revenue is gradually increasing in the government revenue. Government aims to make the tax contribution $50 \%$ of the total government revenue by the year of 2020-2021. Also the present government wants to reach a Tax-GDP ratio of $13 \%$ by 2016 [Outline of Modernization Plan $\{(2011-2016)$ National Board of Revenue (NBR) $\}]$. To reach these goals gift tax can contribute. Currently gift tax is existed but most of the people are unknown about this and even some of the educated people don't know about it. People specially the higher income people should be informed about the gift tax and they should be motivated to pay tax on taxable gifts. They might be motivated by sharing the contribution of tax revenue in the economy and the country as a whole. In some countries inheritance tax and gift tax are one. Presently highest rate of inheritance tax is found in Japan which is $55 \%$ while the average rate for the OECD countries is $15 \%$. In Bangladesh current Tax-GP ratio is $10.5 \%$ only which is very poor compared to other countries. National Board of Revenue (NBR), the tax authority of Bangladesh along with the ministry of finance and other related wings of the government should take necessary measures to enhance the collection of gift tax. The application of laws regarding gift tax can maximize the collection of gift tax. NBR can open a special cell to inform the taxpayers about gift tax and to monitor the gift tax issues.

\section{References}

1. Islam MR. Contribution of Indirect Taxes on GDP of Bangladesh. Asia Pacific J Res. 2016;1:123-18.

2. Shil NC, Masud MZ, Alam MF. Bangladesh Income Tax: Theory and Practice. $9^{\text {th }}$ ed. 2015.

3. Bangladesh Income Tax Ordinance 1984.

4. Gans MM, Soled JA. Reforming The Gift Tax and Making it Enforceable. Boston Uni law Rev. 2007;87(4):759-99.

5. Choudhury D. The need for three-tier tax reform. The Bangladesh Accountant: Jan-Mar. 2017;31-9.

6. Sarker TK. Who bears the Burden of Taxes in Developing Countries? A case of income taxation in Bangladesh. Pak Eco Soc Rev. 2006;44:181-07.

7. Outline of Modernization Plan (2011-2016) National Board of Revenue (NBR), Bangladesh.

8. Joulfaian D. The Federal Gift Tax: History, Law and Economics. US department of Treasury, Office of Tax Analysis. 2007.

9. Retrieved from http://www.taxworld.org/History/ TaxHistory.htm

10. Routh SK. Elements of Hindu Law. $3^{\text {rd }}$ ed. 2013.

11. Gravellee JG. Recent Changes in the Estate and Gift Tax Provisions. Congressional Research Service. 2018. Retrieved from https://fas.org/sgp/crs/misc/R42959.pdf

12. Rowlingson K, McKay S. Attitudes to Inheritance in Britain. 2005.

13. Retrieved from http://www.investopedia.com/terms/i/ inheritancetax.asp

14. Retrieved from https://taxfoundation.org/estate-andinheritance-taxes-around-world/

15. Louis, K. A Framework for Assessing Estate and Gift Taxation, Harvard Law School and NBER.

16. Retrieved from https://www.journalofaccountancy.com/ issues/2009/jul/20091463.html

\section{*Correspondence to:}

Nurul M Zayed

Department of Real Estate

Daffodil International University

Dhaka, Bangladesh

Tel: +2348069202051

Email: zayed.bba@daffodilvarsity.edu.bd 